\title{
Jesus' halakhic argumentation on the true intention of the law in Matthew 5:21-48
}

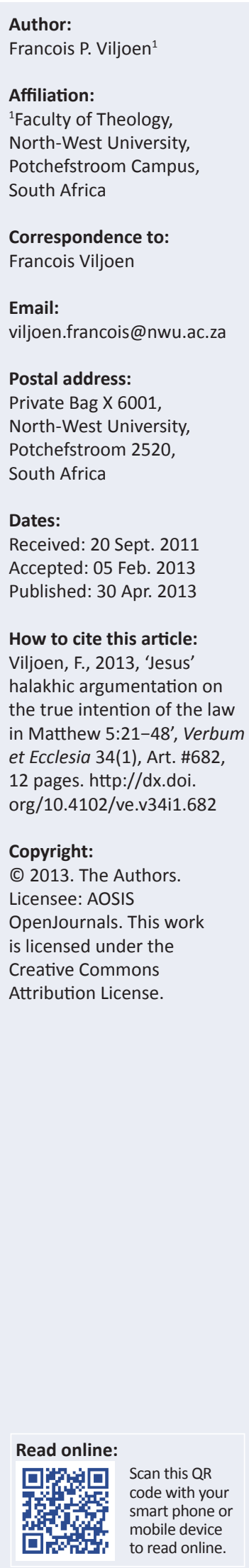

In the time when Matthew wrote his gospel, the interpretation of the Torah became a feature of division. Matthew frequently presented Jesus as being in debate with the Pharisees and scribes on the true intention of the Law. In the Sermon on the Mount Jesus was presented as using the halakhic form of argumentation to counter false assumptions about the meaning of the Torah. Six theses about the Torah were set, followed by Jesus' antitheses. Jesus' alternative interpretations were presented as an authoritative explanation of the true, intended meaning of the Law. Matthew argued that Jesus did not come to abolish the Law and the Prophets, but bring them to fulfilment. In this argument Jesus formulated the higher level of righteousness that is required of his followers.

\section{Introduction}

The central claim of the Sermon on the Mount is that Jesus did not come to abolish the Law and the Prophets, but to reveal their true intension and meaning in contrast to common interpretations of those days (Viljoen 2011:385-407). The fundamental statement about the continuing validity of the law is made in Matthew 5:17-19, after which contrasting interpretations of various laws are given in Matthew 5:21-48 (Sigal 2007:24-27).

Matthew 5:21-48 represents a halakhic ${ }^{1}$ form of debate to urge norms of conduct. There is a series

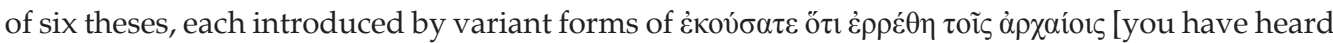
that it was said to the people long ago] (Mt 5:21, 27, 31, 33, 38, 43) and continuing with variant forms of $\dot{\varepsilon} \gamma \omega \grave{~} \delta \dot{\varepsilon} \lambda \dot{\varepsilon} \gamma \omega \dot{v} \mu \tilde{i} v$ [but I tell you] statements of Jesus ${ }^{2}$ (Mt 5:22, 28, 32, 34, 39, 44). Though it is quite common to label the $\dot{\varepsilon} \gamma \grave{\omega} \delta \dot{\varepsilon} \lambda \dot{\varepsilon} \gamma \omega$ v $\mu \tilde{i} v$ [but I tell you] statements as antitheses, this term in itself already represents an assumption. The grammar allows more nuances in translation: 'you have heard, but I (in contrast to that / in addition to that / in agreement with that) say to you' against the current literal interpretation of the Law. The nature of the contrast between the theses and the antitheses can therefore be interpreted in more than one way. It can be said that Jesus merely sharpened and internalised the Torah. He went beyond the literal interpretation of the Torah and broke with the casuistry of the scribes and the Pharisees, but did not revoke the stipulations of the Torah itself. The first, second and sixth antitheses can easily be understood in this way. However, another way of understanding the nature of the contrasts that Jesus poses is to assume that the antitheses indeed involve the abrogation of the Torah itself. The third, fourth and fifth antitheses seem to fit this interpretation.

In an attempt to explain these contrasts Przybylski (1980:81) suggests that the new interpretation of the Law should be understood in the sense of Matthew applying the rabbinic principle of making a fence around the Torah. This hermeneutical principle was used to protect the Law 'by surrounding it with cautionary rules to halt a man like a danger signal before he gets within breaking distance of the divine statute itself' (Moore 1970:259). Jesus would have applied this rabbinic hermeneutical principle to state his argument of upholding the Torah in its finest details. This brings Przybylski to the conclusion that 'the logical antidote to the practice of the relaxing of the commandments would be to make a fence around the Torah' (Przybylski 1980:82). This suggestion sounds convincing when applied to some of the antitheses, but does not adequately answer all the issues.

Other scholars explain the apparent contradiction between Matthew 5:17-19 and Matthew 5:21-48 by arguing that Jesus does not refer to the written Mosaic Law as such in the antitheses, but merely to the oral traditions of the scribes and Pharisees. Barth (1963:93) remarks: 'It

\footnotetext{
1. Halakha guides aspects of day-to-day life. A literal translation yields 'the way to go'. Halakha constitutes the practical application of the 613 mitzvot [commandments] in the Torah as developed through discussion and debate. Halakha has been developed since before $500 \mathrm{BCE}$. It forms a body of intricate judicial opinions, legislation, customs, and recommendations, many of them passed down over the centuries, and an assortment of ingrained behaviours. It became the subject of intense study and debate (Sigal 2007:3-60).
}

2.The Jesus to which this article refers is the Jesus as presented by Matthew, unless it is otherwise specified. 
is plain that the antitheses are not directed primarily against the Old Testament itself, but against the interpretation of it in the Rabbinate.' Patte (1987:78) regards the difference as an antithesis between a literal, narrow interpretation of the Law as practiced by the rabbinate and a broad interpretation as practiced by Jesus. However, when each antithesis is examined individually, it becomes clear that the issue remains quite complicated.

Another scholarly argument is that the antitheses intensify the Law's demands by calling for a higher standard of righteousness. Davies (1963:102) argues that 'we cannot speak of the Law being annulled in the antitheses, but only of its being intensified in its demand, or reinterpreted in a higher key.' Allison (1993) argues that Jesus transcends the traditional commandments by replacing some and making additional commands:

Jesus uses the Scriptures as a point of departure to demand more from his disciples. In most cases he extends the Scripture by interpreting its ethical and societal implications for human living ... but in the fourth (vv. 33-37) and fifth (vv. 38-42) examples he allows part of the Scripture to pass away (vv. 18-19). (p. 184)

Scholars such as Overman (1996:82) and Ridderbos (1987:299) argue that the antitheses do not revoke the Torah. They regard the antitheses as more detailed expositions of the Law. Such an argument fits the antitheses regarding murder, adultery and love of enemies fairly well. However, the antitheses dealing with divorce and the lex talionis [an eye for an eye and a tooth for a tooth] do not really fit this assumption. In more than one case Jesus' interpretation points to a more demanding challenge than the mere literal application of the Law. The Old Testament principle of love for the neighbour is extended to include enemies (Mt 5:43-47). The apparent permission for divorce in Deuteronomy 24:1-4 is withdrawn (Mt 5:31-32). The elaborate system of oaths and vows is simplified to the principle 'Do not swear at all', with the implication that the system of oaths comes from the evil one (Mt 5:33-37)! The lex talionis is replaced by a radical principle: 'Do not resist one that is evil' (Mt 5:38-42). Superficially it is clear that Jesus is opposed to the literal interpretation of the Laws by his contemporaries.

Other scholars hold that Jesus clearly abrogates the commandments of the Old Testament in some instances. Carter (2000:144) makes a remark regarding the fifth and sixth antitheses: 'Oaths and revenge are not part of the life in God's kingdom.' Meier (1976) claims that Jesus' teaching with regard to the lex talionis is:

... perhaps the clearest and least disputable case of annulment in the antitheses. Probably one cannot even speak of a permission being annulled. Such introductory phrases as Deut. 19:21a ('and your eye shall show no pity') indicate an obligatory command rather than a permission. (p. 157)

Bornkamm (2009) argues that the third, fifth and sixth antitheses do not represent a sharpening of the Law as is the case in the first, second and fourth, but, in fact, the abolition of the Law. Consequently, according to Bornkamm (2009:16), the 'better righteousness' of Matthew 5:20 is at least partly concerned with a new Law. Strecker (1971:146) supports the view that the antitheses largely replace the demands of the Old Testament by way of new regulations.

If this is the case, Matthew's treatment of the Torah is seemingly inconsistent. In Matthew 5:17-19 he portrays Jesus as someone who adheres to the Law but who simultaneously initiates a new Law, under pretence of being true to tradition!

In this article I argue that the author of the first Gospel presents Jesus' antithetical arguments about the meaning of the Torah (Mt 5:21-48) to demonstrate how Jesus revealed its true intention. He did not abolish the Law and the Prophets, but fulfilled them (Mt 5:17-20). To support my argument I shall attend to the literary context of the antithetical arguments, the form of Jesus' debate, and then follow with the grammatical interpretation of the respective antitheses. From this investigation conclusions will be drawn.

\section{Literary context of the antithetical arguments}

The Sermon on the Mount forms a literary unit but is also part of Matthew's logical argument about the person and ministry of Jesus. When the antithetical argumentation of Jesus is investigated, it is therefore necessary to consider its literary context, too.

Matthew frequently presents Jesus as being involved in a debate with the Pharisees and scribes about their interpretation of the Torah. The interpretation of several stipulations of the Law had become flash points and make-or-break issues on which differences and divisions in Judaism developed (Dunn 2003:292). Within this environment Jesus' views and practice are presented as contrasting with the legal norms of the day (Moo 1984:15). This resulted in an increasing rejection of Jesus by the Jewish religious leaders and people. Related to this is the fact that the Matthean community who regarded Jesus as their authoritative leader and interpreter of the Torah also felt rejected.

The Sermon on the Mount forms a significant component in Matthew's argument about the true intention of the Torah in contrast to the teachings and praxis of the day. Matthew presents Jesus as a new Moses (Allison 1993:137-270; Floor 1969:34). At the beginning of the Sermon on the Mount (Mt 5:1-2) the Sinai typology is significant (Loader 1997:165). Anticipation is created of a new revelation to be delivered by a new Moses. In the Sermon Jesus elaborates on certain stipulations of the Law as such. This correlates with the well-known concept in Judaism that the Mosaic character could transmigrate to later legislators and teachers (such as Ezekiel). According to 4 Ezra the scribe receives the old revelation of Sinai plus additional, new revelations (Allison 1993:185). Matthew's Jesus describes the nature of the Kingdom of heaven and explains how a citizen of that Kingdom is supposed to act in the present (Lioy 2004:117; Van der Walt 2006:186).

The set of beatitudes (macarisms) in Matthew 5:3-12 functions as the exordium to the Sermon on the Mount. The beatitudes 
contain blessings with implied commands for the followers of Jesus. These beatitudes introduce moral instructions that are to follow in the rest of the sermon (Luz 1990:215). The beatitudes imply that when followers of Jesus adhere to the moral law as he teaches it, their lives will be filled with joy, purpose and eternal hope. Several elements which occur in the antitheses are anticipated in the beatitudes, such as peacemakers being called sons of God (Mt 5:9), being persecuted for the sake of righteousness (Mt 5:10), suffering insults and false accusations for the sake of Jesus (Mt 5:11) and receiving a reward for perseverance (Mt 5:12).

The beatitudes are followed by an exhortation using the metaphors of salt and light to depict the distinctive life of the followers of Jesus (Mt 5:17-20). People become salt when they practice Jesus' teaching on righteous living. The salt and light refer to good deeds that are based on Jesus' interpretation of the Torah (Mt 5:21-47).

The legal statement in Matthew 5:17-20 introduces the main body of Jesus' teaching by using catchwords such as Law and Prophets. This statement functions as the preamble to the six formulations in Matthew 5:21-47. Matthew first provides the fundamental and somewhat abstract statement about the continuing validity of the Law, and then continues to provide practical examples of how the Law should be interpreted. Matthew obviously intended his audience to recognise the harmony between these two sections. Although the antithetical debate does not provide an explicit commentary on the foregoing fundamental statement, it does illustrate the intention of this statement in practice.

Matthew 5:20 functions as a Janus-like hinge in that it is a transitional statement between two sections. The debate about the Law introduced in Matthew 5:17-20 is concluded by emphasising different forms of 'righteousness', and

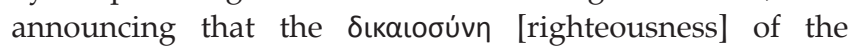
followers of Jesus should exceed that of the scribes and the Pharisees. Simultaneously it creates an expectation that the following series of sayings will provide an explanation and exegetical guide of the implications of this kind of righteousness. The antithetical argumentation is framed by

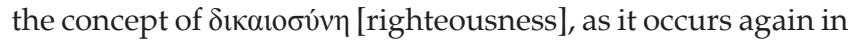
Matthew 6:1, where the hypocritical acts of righteousness of

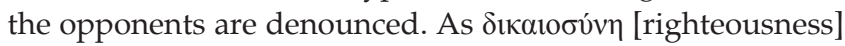
forms a literary inclusio around the antitheses, its meaning forms an important hermeneutical key to the interpretation of the antitheses. Müller (1999:170) remarks that 'the realisation of such righteousness as conforms with God's will ... is a manifestation of the Law's true significance.'

The six antitheses are drawn to a conclusion with $\check{\varepsilon} \sigma \varepsilon \sigma \theta \varepsilon$

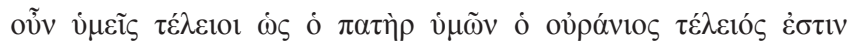

[be perfect, therefore, as your heavenly Father is perfect] (Mt 5:48). This formulation summarises the intention of the

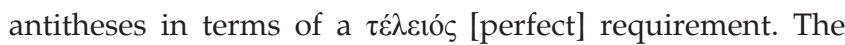
future indicative of the verb $\check{\varepsilon} \sigma \varepsilon \sigma \theta \varepsilon$ [you must be] is usually interpreted as a command. Schweizer (1976:135), however, made the noteworthy comment that this formulation includes a promise. Jesus formulates the statement in such a manner that his disciples may expect divine assistance in striving towards the set goal. The í $\mu \varepsilon i \varsigma_{S}$ [you] in this statement is emphatic. Jesus does not require the Jews who do not follow him or the gentiles to be perfect, but he does require it from his disciples. Being $\tau \dot{\lambda} \lambda \varepsilon 101$ [perfect] implies that they should attain the aim for which God had created them.

These structural markers - the fact that the antitheses function as an explanation of the fundamental statement in Matthew 5:17-20, are drawn to a conclusion with the $\tau \dot{\varepsilon} \lambda \varepsilon$ ió $\varsigma$ [perfect] requirement, and are set within the framework of

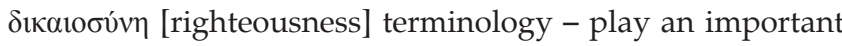
role in the interpretation Jesus' antithetical argumentation.

\section{The form of the debate}

The theses and antitheses differ considerably, but Matthew presents them as a unit. The series has a legal tone as a result of the basic structure which consists of six paragraphs (unique to Matthew), each stating a thesis and followed by Jesus' interpretation of that thesis in contrast to the popular understanding of his day.

Jesus' antithetical debate on the Torah is presented in a highly ordered six-fold scheme. The six theses (or examples) are all introduced by variations of a repetitive formula, which is unparalleled in the Gospels. Either the full formula

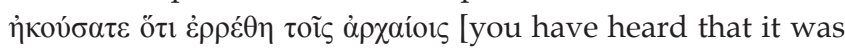
said to the people long ago] (Mt 5:21 and 33), or the medium

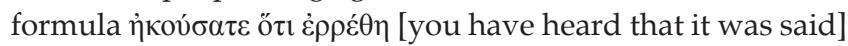

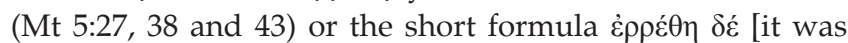
said] (only in Mt 5:31) is used. Matthew constructed the introductory formula with significant parallelisms, to form two triads. As a result parallelisms are formed between the first and the fourth, the second and the fifth, and the third and the sixth in a well organised pattern (see Figure 1).

The second triad is introduces with $\pi \alpha$ á $\iota v$ [again], whilst

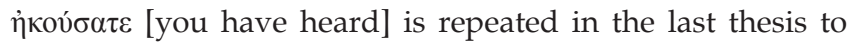
form a conclusion to the series.

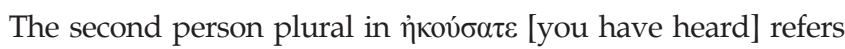
to the disciples of Jesus. Matthew's audience is implied too. The hearing probably refers to the Scriptures as it was read in the synagogue along with the explanations of Jewish teachers.

\begin{tabular}{|c|c|}
\hline Triad 1 & Triad 2 \\
\hline 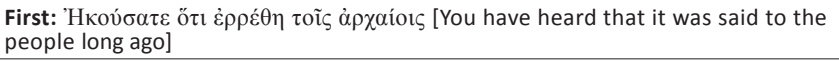 & 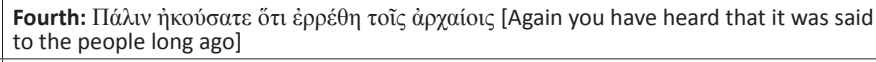 \\
\hline 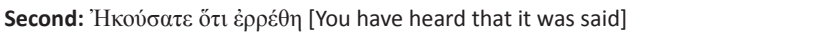 & 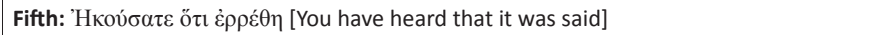 \\
\hline
\end{tabular}

FIGURE 1: Construction of Matthew's introductory formula. 
The reference of the passive form in $\dot{\varepsilon} \rho \rho \dot{\varepsilon} \theta \eta$ [it was said] is not explained easily. If it refers only to the teaching of the scribes, the problem of interpreting the antithesis is solved more easily. However, Matthew always uses this passive form of the verb elsewhere for speaking of God. Furthermore, most of the theses refer to passages or paraphrases from the written Torah, and not from the oral tradition. However, the traditional and sometimes distorted scribal interpretation of the Torah is obviously included, if one considers the

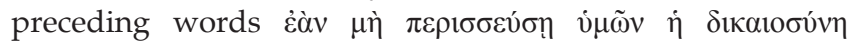

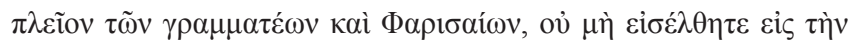

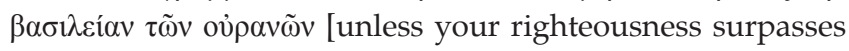
that of the Pharisees and the teachers of the law, you will certainly not enter the kingdom of heaven] in Matthew 5:20. Davies and Allison (2004:510) remark: 'In both Jewish and Christian writings, "it (was) said (by God)" is common for introducing Old Testament quotations.' The uncertainty of how to interpret this passive form of the verb affects one's

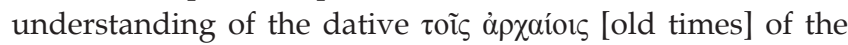
phrase. If $\dot{\varepsilon} \rho \rho \dot{\varepsilon} \theta \eta$ [was said] refers to the speaking of the scribes, the dative can be interpreted as a dative of agency with the verb $\dot{\varepsilon} \rho \rho \dot{\varepsilon} \theta \eta$ [was said]. The King James Bible translates these references as follows: 'Ye have heard that it was said by them of old time ...' However, there is no other example of the dative used in this way by Matthew. The dative more often indicates the audience at whom the words are directed.

The introductory formula is followed by a passage or paraphrase from the written Torah. In Matthew 5:21 an interpretative addition is given as well. The formula used by Jesus suggests that he is quoting the Torah as it was usually heard by his audience.

Each of these statements is then followed by an antithetical response containing the interpretation Jesus gives to the

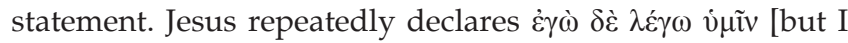
tell you], implying that there are deeper principles to the Law than is commonly assumed. The dominant note, hinted at by the emphatic 'but I tell you', is the independent, authoritative teaching of Jesus. The goal of this teaching is nothing but perfection (Mt 5:48), which demands and receives reaction from the crowds (Mt 7:28-29). Jesus argues that He will pose revisions in halakhah in order to better fulfil the Law (Sigal 2007:70).

There is no analogy of the antitheses of the Sermon on the Mount elsewhere in early Christian literature and they form one of the most intriguing parts of the New Testament. The antithetical debate can, however, be located against the wider background of Judaism, where dissenting groups interacted with their opponents. Daube (1956:55-62) has drawn attention to a rabbinic method of teaching which may lie behind this pattern. He points out that the rabbi might say 'I hear' and then refer to a passage from Scripture. The rabbi then would continue to give a literal but erroneous interpretation of the passage, followed by the true meaning. Daube cites an exposition of the fifth commandment: 'Honour thy father and thy mother. I might understand ... honour them with words only' (Mekhilta on Ex 20:12). The rabbi then explains how the Midrash refutes such an interpretation and how the true meaning goes beyond speech. The expression 'he who hears' is used in the sense of 'he who sticks to the superficial, literal meaning of Scripture'. In Matthew, however, there is no rabbinical argumentation regarding the progressive interpretation of the passage, but only the statement of Jesus, who speaks with supreme authority. Taking this rabbinical method as model for Matthew 5:21-47, he objects against a superficial and therefore strictly limited obedience of the Law that leaves scope for a good deal of ungodly attitude and behaviour (Morris 1992:113).

Foster (2004:80) compares Matthew 5:21-48 with the antithetical debate in the halakhic letter of Qumran (4QMMT). Direct and indirect use is make by 4QMMT of the antithetical form of contrasting two opposing viewpoints in its halakhot to promote the viewpoint of the Qumran community. Similarly Matthew's Jesus also uses the antithetical halakhic arguments to describe the higher form of righteousness required of his followers. Jesus does not merely pose an alternative halakhic position, but gives the authoritative interpretation of the Torah. The Qumran community regarded the right interpretation of the Torah as fundamental to their decision to part from their mother group, for they were striving towards a higher state of righteousness. In Matthew a similar tendency surfaces as the correct interpretation of the Law and true righteousness formed key issues in the Matthean community's parting from formal Judaism.

Loader (1997:173) observes: 'The status of his [Jesus'] antithetical statement is, however, not a second opinion, but an authoritative declaration made on his own God given authority.' Jesus' self-referring announcements are regarded as the highest source of authority for the correct understanding of the Law. Matthew makes the exclusive claim that Jesus is the legitimate interpreter of the Torah:

This is not simply a claim that the group has the right interpretation of the Torah, but this constitutes a higher claim, namely the right to re-interpret the law thereby making its authority subservient to that of Jesus. (Foster 2004:92)

The antitheses therefore explain the issues that led to their schism from Judaism.

\section{Jesus' antithetical arguments about the Torah}

The antithetical arguments function as explanations of the fundamental statement in Matthew 5:17-20 and the call for a higher righteousness for Jesus' followers. There is no easy answer to the question whether Jesus merely interpreted the Old Testament Law or whether he abrogated it. Jesus' six antithetical arguments will be investigated separately in order to find answers and to evaluate the assumption that they do form part of a coherent argument to describe the ethical requirements for the Matthean community. 


\section{The antithetical argument on murder (Matthew 5:21-26)}

The first antithetical argument is the longest of the six statements. It starts with the fullest form of the introductory

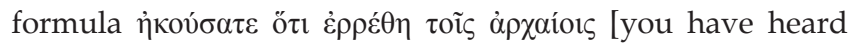
that it was said to the people long ago] (Mt 5:21a). This is followed by a thesis which consists of two elements, the

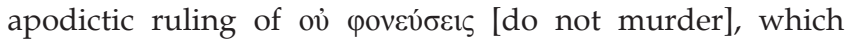
refers to passages from the written Torah (Ex 20:13 and

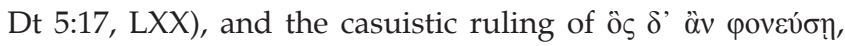

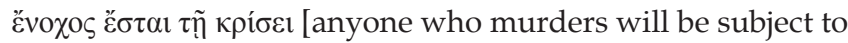
judgement].

The antithetical response to the thesis is given in Matthew 5:22-26. It opens with the introductory formula

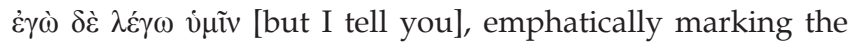
definite and authoritative interpretation of Jesus. France (1985:125) comments: 'This is not a new contribution to the exegetical debate, but a definite declaration of the will of God.' Jesus indicates that the commandment goes further than was commonly assumed. For the people of the day the commandment meant no more than that they were not to kill someone else. Jesus argues that this is just the beginning of the understanding of this command. In contrast to the single thesis in Matthew 5:21, Jesus makes three antithetical statements in Matthew 5:22, demonstrating Matthew's preference of using triadic structures. The statements develop from a general act of anger:

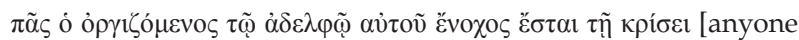
who is angry with his brother will be subject to judgement]

into two specific offences in parallel form:

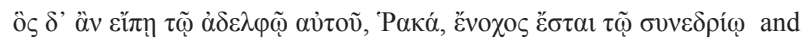

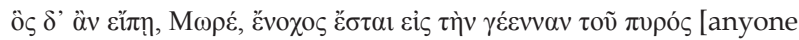
who says to his brother, 'Raca', is answerable to the Sanhedrin], and [but anyone who says, 'You fool!' will be in danger of the fire of hell.]

Matthew's community would recognise their experience of insults by those who taunted them when they heard these two specific offences. In the eyes of God these offences are subject to judgement. Przybylski (1980:82) applies the hermeneutical principle of a fence around the commandment to Matthew 5:21-26. Accordingly the fence consists of the recommendation that one should not even be angry with one's brother, for in this way one obeys the commandment not to kill. The principle might fit this context, but becomes less obvious in some of the antitheses that follow. It is clear, however, that Jesus goes beyond the act of murder as such. He warns against the anger and hatred that gives rise to murder. Though angry thoughts cannot be examined in a human court, they are no less culpable in the sight of God. Jesus urges his followers to also submit their thoughts to God (France 1985:125).

After this threefold antithesis, two examples are given to illustrate Jesus' interpretation in practice. The first example depicts how to avoid hostilities amongst brothers:

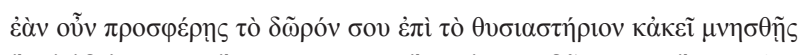

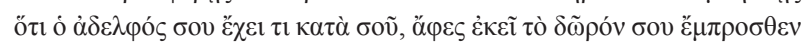

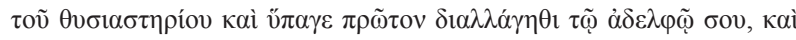

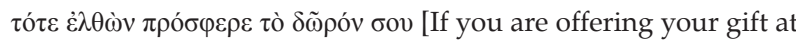
the altar and there remember that your brother has something against you, leave the gift there in front of the altar. First go and be reconciled to your brother, then come and offer your gift.] (Mt 5:23-24)

In this example a shift in the use of pronouns takes place from the third person to the second. Though this may reflect a break in the tradition (cf. Forster 2004:100), it in fact sharpens the personal application of the example to Jesus' (and Matthew's) audience (Hagner 1993:117; Morris 1992:115). This example illustrates the incongruence that can occur between cultic accuracy and an unforgiving attitude. The importance of brotherly reconciliation above punctilious sacrifice correlates with Jesus' consistent emphasis on love for one's neighbour and with the fifth clause of the Lord's Prayer (Mt 6:12), which links the forgiveness of others with the forgiveness of God (Davies \& Allison 2004:516). The words

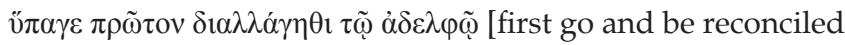
to your brother] are significant. The value of a sacrifice is annihilated when it is approached with a negative attitude. The negative prohibition of the command is interpreted beyond the letter of this stipulation, to the ultimate intention of the Torah. Jesus goes beyond the basic meaning of the Law as stated in Matthew 5:21, in that he urges for reconciliation and the restoration of relationships (Guelich 1982:190). Worshippers should establish priorities. Before they can worship, they must first reconcile (Morris 1992:116). This example reflects something of the strained relations between the synagogue and the Matthean community. Matthew's intention is not only polemical but also pastoral. The tensions between the Matthean community and those who taunt them are reflected, whilst those opponents continue with their superficial cultic punctuality.

The second example returns to the judicial setting:

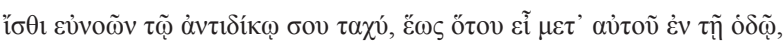

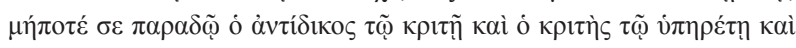

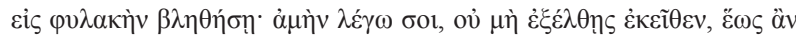

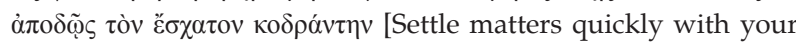
adversary who is taking you to court. Do it whilst you are still with him on the way, or he may hand you over to the judge, and the judge may hand you over to the officer, and you may be thrown into prison. I tell you the truth, you will not get out until you have paid the last cent.] (Mt 5:25-26, [author's own translation])
\end{abstract}

These words once again reflect the strained relations between the Matthean community and its adversaries. Jesus' counterargument is that legal hostilities must be avoided. The negative and minimal meaning of the command not to murder is expanded to include a positive call for reconciliation.

With this extended antithetical statement Jesus argues that

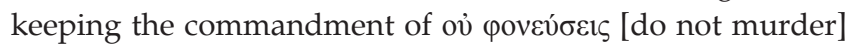
implies much more than had generally been assumed. The deeper implications of God's commandment should be recognised and put into practice. 


\section{The antithetical argument on adultery (Matthew 5:27-30)}

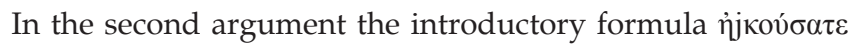
ö $\tau$ \&̇ $\rho \rho \varepsilon \dot{\theta} \theta$ [you have heard that it was said] (Mt 5:27a) and the

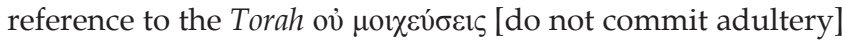
(Mt 5:27b) are shorter than in the first. The formulaic opening

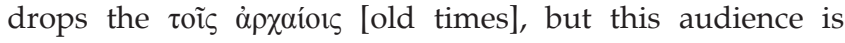
obviously assumed. Then a two-word commandment is quoted from Exodus 20:14 and Deuteronomy 5:18 (LXX) and in this case no corresponding penalty is mentioned for breaking the commandment.

The antithetical statement follows in Matthew 5:28: $\dot{\varepsilon} \gamma \omega \grave{\delta} \delta \dot{\varepsilon}$

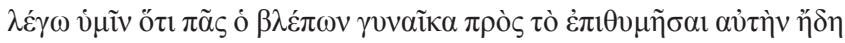

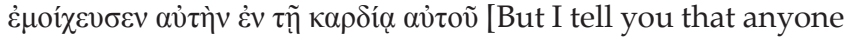
who looks at a woman lustfully has already committed adultery with her in his heart]. With this statement Jesus does not revoke the Law, but states that there is no difference between a lustful heart and adultery. Jesus says that the original intent of this prohibition calls for more than literal compliance; it calls for the removal of the cause of the sin and for attention to the intent of the heart (Betz 1995:231; Meier 1976:136). Jesus even warns against 'thought-adultery' (Foster 2004:105). In many societies of the ancient world it was acceptable for a man to have sexual relations with a woman other than his wife, as long as it did not involve another marriage, as it would then violate the rights of the woman's husband. The key for determining whether a sexual act was adultery or not depended on the woman's marital status. The offence was regarded as being against the man who was the husband or fiancé of the woman (Shields 2006:57). Therefore a man was generally not held to be an adulterer if he engaged in sexual activity outside his marriage unless the new partner was a married or an engaged woman (Morris 1992:122; Sigal 2007:116). The common understanding was that adultery was not so much seen as moral depravity but as the violation of a husband's right to have sole sexual possession of his wife and thus to assure that her children were his (Shields 2006:57). Jesus, however, makes no distinction between male and female in the application of this commandment. Both men as women need to be faithful. As a matter of fact, Jesus specifically warns men against adultery. A man commits adultery with a woman not his wife, whether or not she is anyone else's wife (Sigal 2007:117). Jesus elevates the status of women and forbids men to abuse them. Banks (1975:190) and Luz (1990:296) draw attention to close parallels of this warning in rabbinic literature. The Mekhilta of rabbi Shimon III states: 'He is not to commit adultery ... either by the eye of by the heart.' In Pesiqta Rabbati 24.2 a similar ruling occurs: 'Even he who visualises himself in the act of adultery is called an adulterer.' The Book of Jubilees 20:3-4 urges: 'Let them not fornicate with her after their eyes and hearts.' Yet these Jewish teachers did not parallel the severity of the proverbial elaborations of Jesus.

Twin proverbial applications, demanding drastic actions to avoid the temptation of adultery, follow. The first concerns the eye:

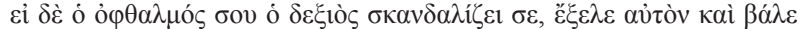

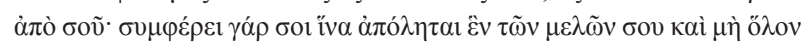

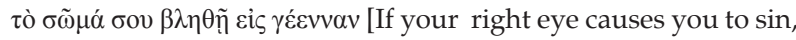
cut it off and throw it away. It is better for you to lose one part of your body than for your whole body to be thrown into hell.] (Mt 5:29, [author's own translation])

and the second the hand:

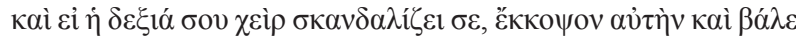

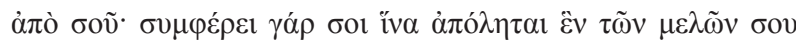

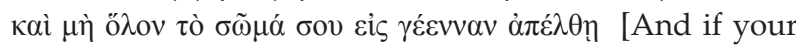
right hand causes you to sin, cut it off and throw it away. It is better for you to lose one part of your body than for your whole body to go to hell.] (Mt 5:30, [author's own translation])

In carefully constructed parallel statements Jesus warns against temptations. He does not advocate self-mutilation, but uses a hyperbole to emphasise the seriousness with which his followers should prevent lustful thoughts. Thus the right eye which, ironically, should keep one from stumbling into a trap, can also be the cause of one's stumbling. If a valuable member such as a right eye causes one to sin, it is better to get rid of it. Parallel to the right eye is the right hand. Its activity can also cause stumbling. One should be willing even to renounce one's favourite activities if they cause stumbling.

With this antithetical argument on adultery, the principle of Matthew 5:20 is once again explained by showing that the righteousness that Jesus requires from his followers should exceed that of the scribes and the Pharisees. Jesus is depicted as the authoritative interpreter of the Torah and is concerned with the inner state that leads to action, rather than the simple outward deed. Jesus does not abolish the commandment, but reveals its true intention.

\section{The antithetical argument on divorce (Matthew 5:31-32)}

The antithetical argument on divorce is the shortest of the series of six. It has no parabolic appendix or pedagogical applications.

Mattew 5:31 comprises of the formulaic opening in its shortest form $\dot{\varepsilon} \rho \rho \varepsilon \dot{\varepsilon} \theta \eta \delta \varepsilon$ [it has been said] and the Torah reference "O $\mathrm{S} \ddot{\alpha} v$

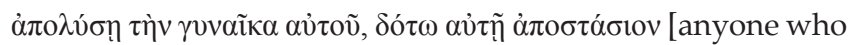
divorces his wife must give her a certificate of divorce]. The Torah reference differs from those in the previous statements in that it does not come from the Decalogue and is not a direct citation from Scripture. The citation alludes to Deuteronomy 24:1. It is important to recognise that in this verse divorce is assumed and not approved (France 1985:127). If a man did indeed divorce his wife, he was commanded to give her a certificate of the divorce. However, in due time not only the certificate as such, but also the divorce itself was regarded as demanded by Moses (cf. Mt 19:7).

It is against this common assumption that Jesus responds

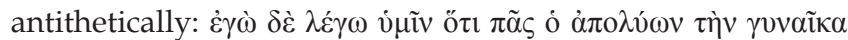

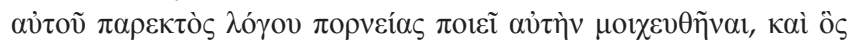




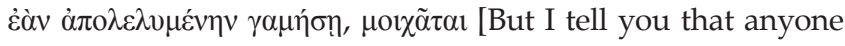
who divorces his wife, except for marital unfaithfulness, causes her to become an adulteress, and anyone who marries the divorced woman, commits adultery]. Scholars such as Meier (1976:140) are of the opinion that this antithesis is a clear example that Jesus did indeed revoke the Mosaic Law that allows divorce. Luz (1990:301), on the other hand, argues that Jesus did not revoke this stipulation as such, but limited the circumstances under which divorce could be permitted to $\pi$ opveía [adultery]. Furthermore, according to this statement the man is assigned a role in the act of adultery as he is seen as causing the wife's adultery, and in the final clause of the divorce statement Jesus prohibits men from marrying divorced women.

The conditions under which divorce can be permitted are based on an interpretation of the ruling of Deuteronomy 24:

If a man marries a woman who becomes displeasing to him because he finds something indecent about her, and he writes her a certificate of divorce, gives it to her and sends her from his house ... (v. 1 [NIV translation])

The ruling is based on the erwat dabar [something indecent] of Deuteronomy 24:1 (Sigal 2007:111-117). The LXX translation took the meaning to be not a sexual misdeed as such, but a general legal reason for divorce as $\grave{\alpha} \sigma \chi \eta \mu o v \pi \rho \grave{\gamma} \gamma \mu \alpha$ [disgraceful act]. However, the translation can also be interpreted as a euphemistical reference to adultery or sexual immorality. The Vulgate, though, translates erwat dabar [something indecent] with aliquam foeditatem [some uncleanness], not referring to sexual indecency as such, but to any kind of impurity. Different interpretations of Deuteronomy 24:1 also appear in rabbinic literature. Rabbi Hillel took the phrase in a broader sense to include actions such as a woman speaking disrespectfully of her husband or burning his food (Str-B 1.314-317). Rabbi Shammai interpreted the indecency in a more narrow sense to include adultery and moral customs of the day, such as a woman appearing in public with her hair down, her arms uncovered or a slit in the side of her skirt (Str-B 1.315) (Guelich 1982:203). The Shammaite school of thought, however, took Deuteronomy 24:1 to refer to adultery as such (Betz 1995:247). From these examples it is clear that Deuteronomy 24:1 was interpreted in various ways. Jesus argues that adultery can be the only ground for divorce, as such an act automatically annuls a marriage by creating a new sexual relation in its place.

Matthew claims that Jesus calls on his people to appreciate the true intention of marriage. Marriage was intended as a lifelong union between man and woman, and was not to be dissolved lightly. Moses did not command divorce, but demanded a certificate from a man if he did indeed divorce his wife. This bill of divorce was intended to protect women against the harshness of men. 'The aim of the legislation is not to condone divorce as such, but to mitigate its evil consequences' (Stonehouse 1944:204). A man could not chase his wife away and afterwards claim that she was still his wife. The bill of divorce implied that the husband gave up his claim on his wife (Morris 1992:121).
The antithetical argument in Matthew 5:31-32 therefore does not negate the commandment on divorce. The sorrowful possibility of divorce is accepted, but the grounds on which divorce can be permitted are strictly limited. The Law is still in place but elevated to a level according to the quest for greater righteousness as stated in Matthew 5:20. Jesus does not abrogate the Law, but reveals its true intention.

\section{The antithetical argument on oaths (Matthew 5:33-37)}

Matthew's Jesus opens the fourth antithetical statement with $\pi \alpha \lambda_{\lambda} v$ [again] which marks a new beginning, and also links the first three statements to the last three in the series of six. This is fittingly followed by the full introductory formula

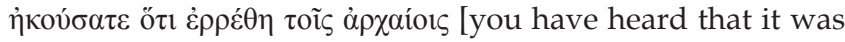
said to the people of long ago] (Mt 5:33a), demonstrating a parallel in the triadic structure.

After the introductory formula the thesis is not given in the exact words of the Old Testament, but in a two part compressed compilation of the teaching on taking oaths (Mt 5:33b). Matthew's Jesus uses both the negative and the positive to emphasise the importance of a sworn testimony. The first part of the composite citation comes as a negative,

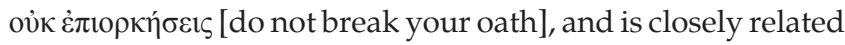
to Leviticus 19:12, 'Do not swear falsely by my name.' It is significant that the LXX version of the text added a reference

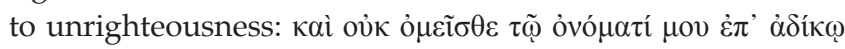
[do not swear in my name unrighteously]. Swearing in God's name is prohibited when it is linked with unrighteousness, and the taking of oaths was necessitated because of it. The LXX version fits well with the plea in Matthew 5:20 for righteousness that exceeds that of the opponents. Matthew usually referred to the LXX version ${ }^{3}$ of the Old Testament in his quotations. As the necessity for taking oaths was associated with the problem of unrighteousness, it explains Jesus' total rejection of oaths for his followers (Foster 2004:116).

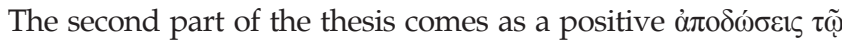

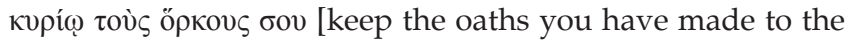
Lord] and relates to Numbers 30:2, Deuteronomy 23:21-23 and Psalms 50:14. It states that vows should be honoured as they are made to the Lord. Such an oath affirms to be true before the Lord. Gundry (1994:92) points out that Matthew substitutes oaths for the vows of Ps 54:14. This shift in terminology demonstrates that the distinction between oaths and vows was generally not kept clear (Davies 1963:129). Matthew's Jesus uses a summative and composite citation of the Old Testament teaching of the topic without making use of lengthy verbatim quotations. This enables him to focus on his authoritative counterproposal.

As with the previous three cases, Jesus' antithetical proposal

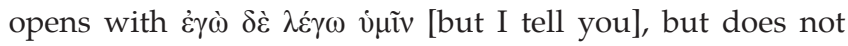
continue with the phrase ö $\tau$ זã $\delta$ ó [anyone who]. Instead, a new fixed form is introduced for the fourth to the sixth 3.At that stage, however, there was no standardised version of the $\mathrm{LXX}$. 
antithetical phrases with a direct appeal, not to a hypothetical third party, but to the audience who are directly instructed to conform to the imperative of the antitheses. This second person group are historically seen as the disciples of Jesus, but in the narrative world as the auditors of Matthew's Gospel (Foster 2004:120). The fourth antithesis reads $\mu$ iे ỏ $\mu$ ó $\sigma \alpha$ ő $\lambda \omega \varsigma$ [do not swear at all] (Mt 5:34a). Apparently the system of oaths is undercut with a simple contrasting command not to swear at all. Some scholars view this prohibition as a clear-cut revoking of the Old Testament legislation (e.g. Meier 1976:150). This assumption is

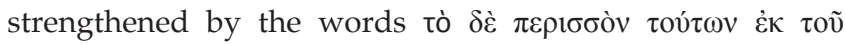

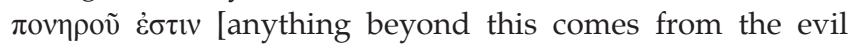
one] (Mt 5:37). This issue becomes problematic indeed, as the Old Testament commanded the taking of an oath in specific cases, for example when a neighbour's goods were lost or stolen whilst another man was supposed to safeguard it (Ex 22:6-7, 10), or when a woman was suspected of adultery (Nm 5:19-22). Furthermore Deuteronomy 6:13 and Deuteronomy 10:20 regulate the taking of oaths in general. The impression is that Matthew's Jesus intentionally presents this issue in the form in which the Jews commonly understood the issue. It seems that people thought that a lie between people did not concern God, but when the divine Name was evoked, one could expect to be punished as the Lord's honour was at stake (Morris 1992:123). Swearing implied self-cursing if one did not speak the truth but did not appeal to God. The implication was that one's words needed to be truthful only when an oath was sworn.

Matthew's Jesus continues his counterproposal with a motivation for this imperative not to swear at all. He does this in two sections. The first section consists of three parallel ways to avoid the divine name when taking oaths (Mt 5:34b-35) and then proposes a simple alternative to oaths (Mt 5:36).

With triadic parallelism Matthew's Jesus refers to established circumlocutions for the divine name in taking oaths. It seems that people took oaths lightly and easily. Oaths played a large part in Judaism. The Mishnah has a complete tractate on oaths (Shebu'ot). Three classes are identified with examples of valid and invalid oaths (Morris 1992:122).

With three examples (Mt 5:34b-25) Matthew's Jesus rules out three possible oath referents, that is heaven, earth and Jerusalem, ${ }^{4}$ which primarily reflects the Jewish notion of avoiding the use of the Tetragrammaton. ${ }^{5}$

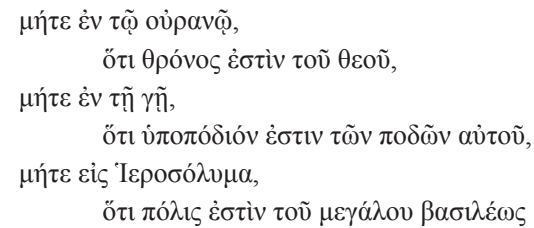

4. Without necessarily indicating a direct textual relation, James $5: 12$ also states a threefold form when taking oaths: 'Above all, my brothers, do not swear - not by heaven or by earth or by anything else.'

5.According to Deuteronomy 6:13 and Deuteronomy 10:20 oaths were to be made in God's name. By the first century, however, the Jews would no longer pronounce his name, and therefore substitutes for God's name were used (Davies \& Allison 2004:536).

\author{
[either by heaven, \\ for it is God's throne, \\ or by the earth, \\ for it is his footstool, \\ or by Jerusalem,
}

for it is the city of the Great King].

Morris argues that the Jews had lengthy discussions on when an oath should be considered binding. 'People would swear by heaven or earth or a similar oath and later claim that they were not bound by that oath because God was not mentioned' (Morris 1992:124). ${ }^{6}$ Jesus, however, links a ötı [for] statement to each referent to indicate how that oath imposes upon the divine realm in any case. These statements are probably reminiscent of Isaiah 66:1.7 Jesus ridicules such a circumlocution of the binding of oaths.

Matthew 5:36 then rejects another form of taking an oath:

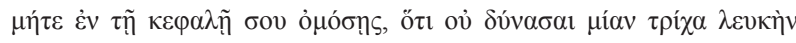

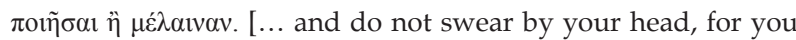
cannot make even one hair white or black.] (Mt 5:36, [author's own translation]

This fourth statement differs in style and content from the previous three. It is not a positive statement about the realm of God, but a negative one concerning human powerlessness. The reason for not swearing moves from the greatness of God to the littleness of humans. The reason for not taking an oath is not the fear of the Lord, but the impotence of humans (Morris 1992:125). With these four reasons the oathtaking habits of the opponents of Jesus and the Matthean community are clearly parodied.

In the final verse of the fourth antithetical statement the

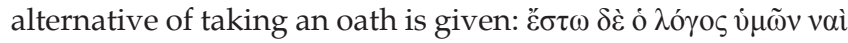
vaí, où oü·[simply let your 'yes' be 'yes' and your 'no', 'no'] (Mt 5:37a). ${ }^{8}$ He concludes the antithesis with a remark that

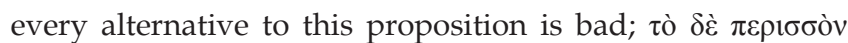

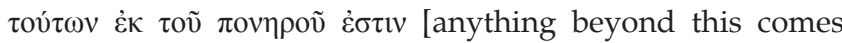
from the evil one] (Mt 5:37b). As mentioned before, these concluding words compel some scholars to assert that this clearly implies an abrogation of the stipulations of the taking of oaths. In an attempt to unravel the issue, Betz (1995:271)

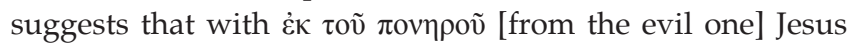
alludes to magical formulations from the demonic realm: 'Overtones of demonic evil cannot be denied, because "oath"' was understood since Hesiod to be a demonic being.'

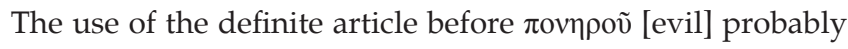
refers to the personification of evil (Foster 2004:121). It is not necessary, however, to link Jesus' negative pronouncement about oaths to Hesiod in order to understand it. Jesus simply argues that it should never be necessary for his followers to swear an oath. Their words should always be reliable, so that nothing but straightforward statements should be needed from them. The righteousness of the followers of Jesus should be of such high order that their statements would be 6.According to Shebu'ot $4: 13$ oaths 'by heaven or by earth' are not binding. 7.Swearing 'by the earth' does not avoid the link with God, for God says: 'Heaven is my throne, and the earth is my footstool' (Is 66:1).

8.This conclusion is also closely related to the concluding words of James 5:12: 'Let your "Yes" be yes, and your "No", no, or you will be condemned.' 
thoroughly reliable and the taking of an oath unnecessary. ${ }^{9}$ Their 'greater righteousness' (Mt 5:20) will be demonstrated in this way. ${ }^{10}$

As with the previous antithetical statements, Jesus argues that if his hearers were to return to the ideal of a truthful and righteous society, the taking of oaths would become unnecessary. The taking of oaths is actually an admission of society's failure to be truthful.

\section{The antithetical argument on retaliation (Matthew 5:38-42)}

With the fifth argument Jesus continues with the theme of a higher form of ethics and righteousness. Jesus not only instructs his followers not to retaliate, but also asks them to do more than their enemies demand of them.

The introductory formula of the second argument of the second group of three parallels the exact form of the

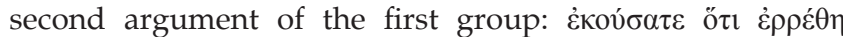
[you have heard that it was said] (Mt 5:38a). This once again demonstrates an aspect of the careful structuring of the entire argumentative sequence. As in the third and fourth argument, this formula is followed by a summary of Torah legislation rather than a verbatim quotation. The

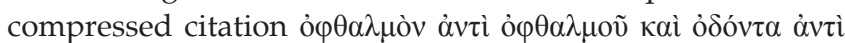
ódóvtos [eye for eye, and tooth for tooth] (Mt 5:38b) refers to three passages from the Pentateuch, Exodus 21:24, Leviticus 24:20 and Deuteronomy 19:21. It is important to realise that the lex talionis was not intended to sanction revenge as such, but to prevent excesses of punishment. The law regulated equivalent compensation without respect of person. ${ }^{11}$

Although it is a slightly modified version, the emphatic introduction of Jesus' counterproposal is similar to that of the previous antithesis $\dot{\varepsilon} \gamma \omega \dot{\omega} \delta \dot{\varepsilon} \lambda \dot{\varepsilon} \gamma \omega$ vं $\mu \mathrm{ĩv}$ [but I tell you]. The imperative that follows denounces any form of retaliation $\mu$ in $\dot{\alpha} \nu \tau \iota \sigma \tau \tilde{\eta} v \alpha \iota \tau \tilde{~} \pi$ $\pi \eta \eta \rho \tilde{~[d o ~ n o t ~ r e s i s t ~ a n ~ e v i l ~ p e r s o n] ~(M t ~ 5: 39 a) . ~}$ The fact that Matthew intentionally portrays the lex talionis as the Jewish norm signifies the strained relations between his community and the Jewish community from which it had separated (Broer 1994:20). The 'bad one' probably refers to unjust religious opponents and oppressors of the community (Hare 1967:122). Matthew's Jesus demands that they do not retaliate, specifically not under these circumstances.

Matthew follows the imperative of how the evil person should not be resisted with three specific examples (Mt 5:39b-41):

9.Matthew's negative critique of oaths surfaces in several incidents: Matthew's Jesus rejects the misuse of the Korban vow (Mt 15:3-6) and the hypocritical use of vows by the scribes and the Pharisees (Mt 23:16--22). False testimonies are brought in against Jesus during his trial (Mt 26:59-62), but when Jesus is instructed to speak under oath, he replies without an oath (Mt 26:63-64). Peter denies Jesus, the second and third time under oath (Mt 26:74-74).

10.A similar prohibition of the swearing of oaths also occurs in the Damascus Document of Qumran (Vermes 1968:108). Josephus writes about the Essenes: 'Any word of theirs has more force than an oath; swearing they avoid, regarding it as word of theirs has more force than an oath; swearing they avoid, regarding it as God stands condemned already' (War. 2:135).

11.The lex talionis had also been expressed in the Code of Hammurabi (dd. 18th century BC; Morris 1992:126).

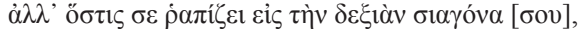

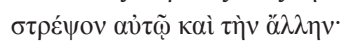

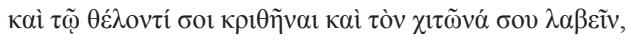

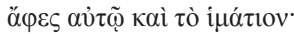

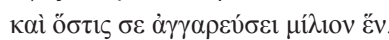

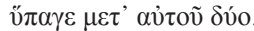

[but if someone strikes you on the (your) right cheek turn to him the other also

and if someone wants to sue you and take your tunic

let him have your cloak as well

if one forces you to go one kilometre

go with him two kilometres.] (Mt 5:39b-41, [author's own translation])

The first illustrative example (Mt 5:39b) presents a slightly fuller form of the saying also found in Luke 6:29a. Jeremias (1963:29) suggests that this example refers to insults the audience had to suffer on behalf of Jesus. A slap on the right cheek by a right-handed person probably refers to a slap with the back of the hand. Jews regarded this kind of slap as especially insulting. According the Mishnah, such an action carried a double fine (Baba Qammah. 8:6).

The second example (Mt 5:40) is also paralleled by Luke 6:29b, though in a variant form. Once again followers of Jesus are urged to avoid any confrontation with their opponents and oppressors. The proper response to an opponent who deprives a disciple of his inner garment is not to resist, but to give the outer garment as well. The outer garment was more expensive and one that even the poorest had the right to keep, as it was illegal to take it away permanently (Ex 22:26-27;Dt 24:12-13). This example reveals an aspect of the social situation of the Matthean community who suffered a form of quasi-legal prosecution by its opponents (Foster 2004:128).

The third example (Mt 5:41) is unique to Matthew. This saying resembles the Roman practice of requisitioning the transportation of goods. This example probably anticipates the story of the Roman soldiers who requisitioned Simon of Cyrene to carry the cross of Jesus (Gundry 1994:94). The evangelist thereby indicates a link between Jesus' suffering and the experience of his followers.

These three examples reflect something of the turmoil which the Matthean community experienced because of their beliefs. In all three cases provocative and even subversive contrasts are proposed against the misuse of power which often rules the world (Luz 1990:328). 'The aggression enacted by the adversaries of the community is to be overcome by the non-violent reaction of group members' (Foster 2004:125).

After the three specific examples, Matthew 5:42 concludes

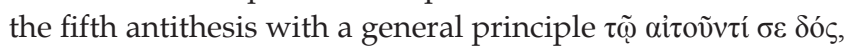

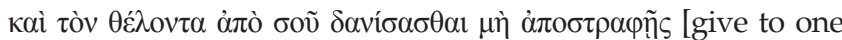
who asks you, and do not turn away from the one who wants to borrow from you].

Some scholars (e.g. Foster 2004:122; Guelich 1982:224; Meier 1976:157) see the denouncement in this antithesis as another 
example of the annulment of the judicial stipulations of the Torah. However, when Jesus' argument is read together with his demand for greater righteousness in his community, a different scenario appears. Jesus requires an unselfish attitude regarding one's own rights and a positive concern for others. With this argument Jesus once again wishes to demonstrate a higher form of righteousness that should distinguish his followers from their opponents.

\section{The antithetical argument on love for enemies (Matthew 5:43-47)}

The theme of higher righteousness amidst persecution is continued in the final antithesis of the series. The extended treatment of the topic of persecution in the final beatitude (Mt 5:11-12) is picked up again in the final argument. The threat of persecution was very real for Matthew's audience was because of their break with the synagogue, resulting in an existence outside their familiar religious and social environment.

As expected, the introductory formula corresponds with that of the fourth argument, but in a more complete form:

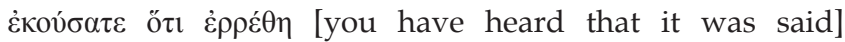
(Mt 5:43a). This extended version is also found in the second (Mt 5:27) and fifth (Mt 5:38) statements. It forms a climactic ending but also refers to the role of hearing in the context of persecution.

The thesis to which Jesus responds consists of two

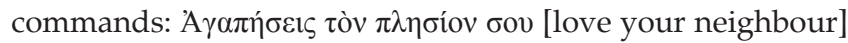

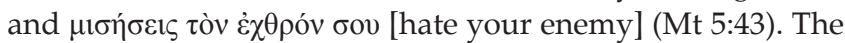
first command refers to $\operatorname{Lv} 19: 18$, but the final element of 'as yourself' is dropped. Morris (1992:129) suggests that this omission can be assigned to the scribes lowering the standard set in Leviticus. Jesus may here refer to their derived attitude regarding this command. However, in previous theses Matthew also offered references to the Law in abbreviated forms. It is more probable that Matthew uses the abbreviated forms to focus on the antithesis that follows, whilst the full reference is assumed. This abbreviated form also allows him to form a parallelism with the second command. The second command on hating enemies does not have a direct parallel in the Old Testament. The teaching in the Old Testament with regard to enemies is complex. Elements of hating enemies can be found in several texts such as Exodus 34:12 and Deuteronomy 7:2; 20:16; 23:4, 7. The Psalmist also speaks of hating those who hate God (e.g. Ps 139:21-22). On the other hand, the Old Testament also commands love to resident aliens (Lv 19:34) and help for enemies (Ex 23:4-5 and Pr 25:21-22). Matthew probably responds to a popular understanding of the love for neighbours which in practice lead to a negative attitude towards enemies. This attitude appears strongly in the Qumran Manual: 'They may love all the sons of light ... and hate all the sons of darkness' (1 QS 1:3-4, 9-10).

As in the previous five antitheses the emphatic contrasting

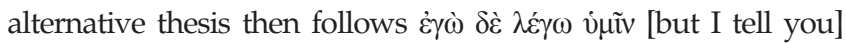

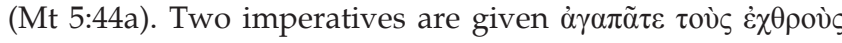

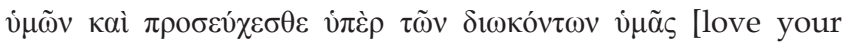
enemies, and pray for those who persecute you] (Mt 5:44bc) which oppose the second imperative of verse 43 to 'hate your enemies'. The counterproposal exhibits parallels with Luke 6:27-28, ${ }^{12}$ though Matthew's variant draws elements from the final beatitude in Matthew 5:11-12. ${ }^{13}$ Matthew 5:44 refers to persecution as does Matthew 5:11, 12, and reflects the persecution the Matthean community feared and somehow experienced. This could have caused bitterness within the community and therefore Matthew urges them to love their enemies and to pray for those who persecute them. Love is combined with prayer for persecutors. It is more than a sentimental feeling, but an honest desire for their good. With this counterproposal Matthew's Jesus upholds and intensifies the command to love one's neighbour (Mt 5:43b), and also counters emerging attitudes to hate one's enemy (Mt 5:43c). This counter-proposal should therefore not be seen as a revocation of the Torah as such, but of a deviated popular understanding of the love commandment. Jesus rejects a negative attitude that developed from Torah tradition.

With the reminder to the community that they are sons of God, verse 45 continues the theme that there should be no

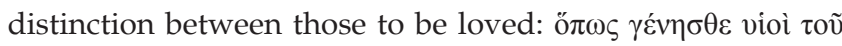

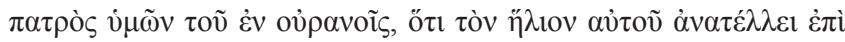

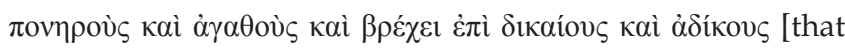
you may be sons of your Father in heaven. He causes the sun to rise in the evil and the good, and sends rain on the righteous and the unrighteous]. This promise is thematically linked with the seventh beatitude, namely that peacemakers will be called sons of God (Mt 5:9), and also a reference to evil (Mt 6:11) and the heavens (Mt 5:12) in the extended last beatitude. The love of the followers of Jesus is based on the love of God. God's good gifts of sunshine and rain are given to all, evil as well as good. Jesus' followers must show the same generosity.

Matthew 5:46-47 presents the second reason for Jesus' alternative command in a carefully constructed isocolon. Each part consists of a conditional clause followed by two double rhetorical questions:

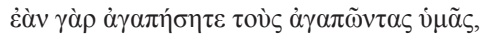

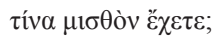

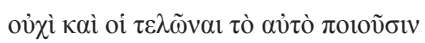

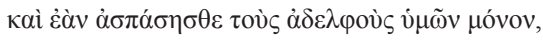

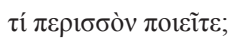

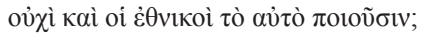

[For if you love those who love you, what reward will you get?
}

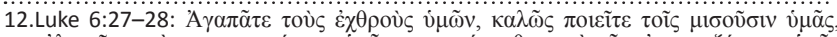

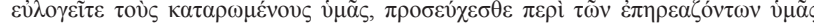
[Love your enemies, do good to those who hate you, bless those who curse you, pray for those who ill-treat you].

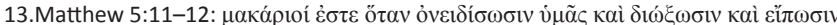

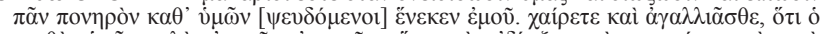

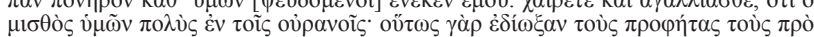
vं $\mu \tilde{\omega}$ [Blessed are you when people insult you, persecute you and falsely say all kinds of evil against you because of me. Rejoice and be glad, because great is your reward in heaven, for in the same way they persecuted the prophets who were before you] 
Are not even the tax collectors doing that?

And if you greet only your brothers,

What are you doing more than others?

Do not even the pagans do that?] (Mt 5:46-47, [author's own translation]

Earlier themes in Matthew 5 are taken up with the mention of reward (see Mt 5:12) and righteousness (see Mt 5:20). Both these questions demand the greater righteousness that is required from the followers of Jesus, as stated in Matthew 5:30. They are called to more than an internally focused love (Foster 2004:137).

The isocolon illustrates the implications of the love command. The verb $\dot{\alpha} \sigma \pi \alpha ́ \sigma \eta \sigma \theta \varepsilon$ [you greet] is parallel to $\dot{\alpha} \gamma \alpha \pi \eta \dot{\sigma \eta} \tau \varepsilon$ [you love], with the implication that it means in this context to 'show favour towards' (Hagner 1993:135). The Jewish greeting was 'peace', which implied a prayer. It may be that the Matthean community, because of their alienation from the synagogue, had refused to greet their fellow Jews (Betz 1995:959).

The love that Jesus requires extends outside the 'in-group' to include outsiders and opponents. Such an attitude depicts the higher form of ethics required of followers of Jesus.

\section{Being perfect as conclusion of the series of antithetical arguments (Matthew 5:48)}

Matthew 5:48 is directly linked to the last antithetical statement but also forms the conclusion of the series of six: ”Е $\sigma \varepsilon \sigma \theta \varepsilon$ oũv [Be perfect, therefore, as your heavenly Father is perfect].

This imperative is linked to the call for greater righteousness

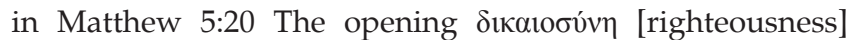
(Mt 5:20) and the closing $\tau \dot{\lambda} \lambda \varepsilon$ iós [perfect] (Mt 5:48) form an inclusio of the series and emphasise Matthew's calling for a higher ethic for his community. This standard is set by the authoritative interpretation of the Law by Jesus. The command is set as a future indicative form of the verb. Grammatically such a form implies a command, though Morris (1992:133) proposes that Jesus here probably suggests a promise as well. His followers can depend on divine assistance.

\section{Conclusion}

Matthew presents Jesus' teaching on the Law in a congruent manner. Jesus' antithetical arguments explain the higher form of righteousness that is required of his followers. This would distinguish them from other Jewish movements. Jesus quoted and abbreviated certain commandments from the Law whilst alluding to a common understanding of those commandments.

Jesus introduces a literal but misleading understanding of

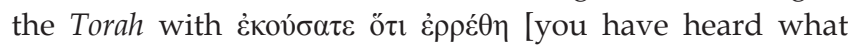
was said] theses. He then follows with opposing $\dot{\varepsilon} \gamma \grave{\omega} \delta \dot{\varepsilon}$ $\lambda \dot{\varepsilon} \gamma \omega$ v́ $\mu \mathrm{i} v$ [but I tell you] antitheses. Matthew presents Jesus' antithetical statements not as a second opinion, but as the authoritative declaration made by the Son of God to reveal the true intention of that stipulation:

- Matthew 5:21: Moses forbade murder (Ex 20:13; Dt 5:17). Matthew 5:22: Jesus argues that this commandment implies more than physical murder and includes hatred. The commandment actually requires a spirit of reconciliation.

- Matthew 5:27: Moses condemned adultery (Ex 20:14; Dt 5:18). Matthew 5:28: Jesus argues that this commandment also includes adulterous thoughts, even those of men who were not usually thought to be adulterers.

- Matthew 5:31: Moses ordered a formal certificate in case of divorce (Dt 24:1-4) which was understood as a permission to divorce.

Matthew 5:32: Jesus argues that the certificate was intended to protect woman in a harsh situation and not as a means of easily dissolving a marriage. He restricts the permission for this formal certificate to cases where divorce has already occurred de facto because of adultery.

- Matthew 5:33: Moses gave rules for taking oaths (Lv 19:12). Matthew 5:34: Jesus argues that the taking of oaths is only necessary in an unjust society. In a truthful society oaths should not be taken at all.

- Matthew 5:38: Moses recommended the precept 'eye for eye, tooth for tooth' (Ex 21:24; Lv 24:20; Dt 19:21). Matthew 5:39: Jesus argues that retaliation should be completely avoided and that benevolence is required by the sufferer for the oppressor.

- Matthew 5:43: Moses required love for the neighbour ( $\mathrm{Lv}$ 19:18), which was understood in the sense that enemies could be hated.

Matthew 5:44: Jesus argues that the love commandment does not exclude enemies. Love for the enemy, in fact, love for all is required.

These antithetical arguments of Jesus caused great amazement (Mt 7:28-29).

Matthew argues that Jesus stated the less literal meaning, but the true intention of these commandments. Jesus did more than abrogating or even confirming the theses; he transcended them.

\section{Acknowledgements Competing interests}

The author declares that he has no financial or personal relationship(s) which may have inappropriately influenced him in writing this article.

\section{References}

Allison, D.C., 1993, The new Moses. A Matthean typology, T \& T Clark, Edinburgh

Banks, R.J., 1975, Jesus and the Law in the Synoptic tradition, Society for New Testament Studies Monograph Series 28, University Press, Cambridge.

Barth, G., 1963, 'Matthew's understanding of the Law', in G. Bornkamm, G. Barth \& H.J. Held (eds.), Tradition and interpretation in Matthew, pp. 59-164, SCM, London.

Betz, H.D., 1995, The Sermon on the Mount including the Sermon on the Plain (Matthew 5:3-7:27 and Luke 6:20-49), Hermeneia: A critical and historical commentary on the Bible Series, Fortress Press, Minneapolis. 
Bornkamm, G., 2009, 'Studien zum Matthäus-Evangelium', Wissenschaftliche Monographien zum Alten und Neuen, vol. 125, Neukirchener Verlag, NeukirchenVluyn.

Broer, I., 1994, Die Seligpreisungen der Bergpredigt: Studien zu ihrer Überlieferung und Interpretation, Bonner biblische Beiträge, Königstein im Taunus, Hanstein.

Carter, W., 2000, 'Matthew and the margins. A socio-political reading', Journal for the study of the New Testament, suppl. ser. 204.

Davies, W.D., 1963, The setting of the Sermon on the Mount, University Press, Cambridge.

Davies, W.D. \& Allison, D.C. 2004, Matthew 1-7, vol. 1, International Critical Commentary, T \& T Clark, London \& New York.

Daube, D., 1956, The New Testament and Rabbinic Judaism. Jordan Lectures in Comparative Religion, Athlone Press, London.

Dunn, J.D.G., 2003, Jesus remembered. Christianity in the making, vol. 1, Eerdmans, Grand Rapids.

Floor, L., 1969, De nieuwe exodus. Representatie en inkorporatie in het Nieuwe Testament, Potchefstroom University for Higher Christian Education, Potchefstroom (now North-West University).

Foster, P., 2004, Community, law and mission in Matthew's Gospel, Wissenschaftliche Untersuchungen zum Neuen Testament, Mohr Siebeck, Tübingen.

France, R.T., 1985, Matthew, Tyndale New Testament Commentaries, Intervarsity Press, Nottingham

Guelich, R.A., 1982, The Sermon on the Mount: A foundation for understanding, Word, Waco.

Gundry, R.H., 1994, Matthew: A commentary on his handbook for a mixed church under persecution, Eerdmans, Grand Rapids.

Hagner, D.A., 1993, Matthew 1-13, Word Biblical Commentaries 33a, Word Books, Dallas.

Hare, D.R.A., 1967, The theme of persecution of Christians in the Gospel according to Matthew, Society for New Testament Studies Monograph 6 University Press, Cambridge. http://dx.doi.org/10.1017/CBO9780511659584

Jeremias, J., 1963, The Sermon on the Mount, Athlone Press, University of London London.

Lioy, D., 2004, 'The Decalogue in the Sermon on the Mount', Studies in Biblical Literature 66, Peter Lang, New York.
Loader, W.R.G., 1997, Jesus' attitude towards the Law:A study of the Gospels, Wissenschaftliche Untersuchungen zum Neuen Testament 2, Reihe, Mohr Siebeck, Tübingen.

Luz, U., 1990, Matthew 1-7, A commentary, T \& T Clark, Edinburgh.

Meier, J.P., 1976, Law and history in Matthew's Gospel, Biblical Institute Press, Rome.

Moo, J.M., 1984, 'Jesus and the authority of the Mosaic Law', Journal for the Study of the New Testament 20, 3-49. http://dx.doi.org/10.1177/0142064X8400702001 the New Testament 20, 3-49. http://dx.doi.org/10.1

Morris, L., 1992, The Gospel according to Matthew, Eerdmans, Grand Rapids.

Moore, G.F., 1970, Judaism in the first centuries of the Christian Era. The age of the Tannaim. University Press, Harvard.

Müller, M., 1999, 'The theological interpretation of the figure of Jesus in the Gospel of Matthew: Some principle features in Matthean Christology', New Testament Studies 44, 157-173. http://dx.doi.org/10.1017/S002868859800157X

Overman, J.A., 1996, Church and community in crisis: The Gospel according to Matthew, Trinity Press, Valley Forge.

Patte, D., 1987, The Gospel according to Matthew: A structural commentary on Matthew's Faith, Fortress Press, Philadelphia.

Przybylski, B., 1980, Righteousness in Matthew and his world of thought, Cambridge University Press, Cambridge.

Ridderbos, H.N., 1987, Matthew, Zondervan, Grand Rapids.

Schweizer, E., 1976, The Good News according to Matthew, SPCK, London.

Shields, M.E., 2006, 'Adultery', in K.D. Sakenfeld (ed.), The new interpreter's dictionary of the Bible A-C Volume 1, p. 57, Abingdon Press, Nashville.

Sigal, P., 2007, 'The halakhah of Jesus of Nazareth according to the Gospel of Matthew', Studies in Biblical Literature 18, Brill, Leiden.

Stonehouse, N.B., 1944, The witness of Matthew and Mark to Christ, Tyndale Press, London.

Strecker, G., 1971, Der Weg der Gerechtigkeit: Untersuchung zur Theologie des Matthäus, Vandenhoeck \& Ruprecht, Göttingen.

Van der Walt, T., 2006, Die Messias het gekom!, Potchefstroomse Teologiese Publikasies, Potchefstroom.

Vermes, G., 1968, The Dead Sea Scrolls in English, Penguin, London.

Viljoen, F.P., 2011, The foundational statement in Matthew 5:17-20 on the continuing validity of the law', In die Skriflig 45(2), 385-407. http://dx.doi.org/10.4102/ids. v45i1\&2.20 